\title{
Cholestasis sepsis at neonatology ward and neonatal Intensive Care Unit Cipto Mangunkusumo Hospital 2007 : incidence, mortality rate and associated risk factors
}

\author{
Kadim Sungkono Bachtiar ${ }^{1}$, Hanifah Oswari², Jose RL Batubara ${ }^{3}$, Idham Amir ${ }^{4}$, Abdul Latief ${ }^{5}$, Kemas Firman ${ }^{6}$
}

\begin{abstract}
Abstrak
Ikterus pada kolestasis merupakan refleksi dari keadaan patologis yang serius. Kolestasis-sepsis adalah suatu bentuk kolestasis hepatoselular yang timbul pada saat atau setelah proses sepsis akibat gangguan transpor empedu. Penelitian ini adalah penelitian kohort terhadap pasien sepsis neonatorum yang dirawat di Divisi Neonatologi Departemen IKA FKUI-RSCM antara Februari sampai dengan Juni 2007. Tujuan penelitian ini adalah mengetahui angka kejadian kolestasis intrahepatik, faktor resiko terjadinya kolestasis dan angka kematian pada sepsis neonatorum dengan kolestasis. Dari 138 subyek, didapatkan angka kejadian kolestasis intrahepatik sebesar 65,9\%. Faktor-faktor risiko yang diteliti secara statistik tidak ada yang bermakna terhadap terjadinya kolestasis. Angka kematian sepsis neonatorum dengan kolestasis 52,8\%. (Med J Indones 2008; 17: 107-13)
\end{abstract}

\begin{abstract}
Cholestatic jaundice represents serious pathological condition. Septic-cholestasis is a kind of hepato-cellular cholestasis that occured during or after sepsis caused by biliary flow obstruction. This is a cohort study from February to June 2007 on neonatal sepsis patients at Neonatology ward Department of Child Health Faculty of Medicine University of Indonesia-Cipto Mangunkusumo General National Hospital. Aim of this study is to find out the incidence of intrahepatic cholestasis in neonatal sepsis, associated risk factors, and mortality rate in neonatal cholestasis-sepsis. From 138 neonatal sepsis patients, the incidence of intrahepatic cholestasis is $65.9 \%$. None of the risk factors tested in this study showed statistically significant result. Mortality rate of neonatal cholestasis-sepsis is 52.8\%. (Med J Indones 2008; 17: 107-13)
\end{abstract}

Keywords: cholestasis intrahepatic, neonatal sepsis, cholestasis sepsis, conjugated hyperbilirubinemia

Jaundice can occured in neonatal sepsis. Despite it's recognition since the 19th century, only recently had studies reveal the role of mediators in pathophysiology of

1 Department of Child Health, Faculty of Medicine University of Indonesia, Cipto Mangunkusumo Hospital, Jakarta, Indonesia

2 Division of Gastrohepatology, Department of Child Health, Faculty of Medicine University of Indonesia,Cipto Mangunkusumo Hospital, Jakarta, Indonesia

3 Division of Endocrinology, Department of Child Health, Faculty of Medicine University of Indonesia, Cipto Mangunkusumo Hospital, Jakarta, Indonesia

4 Division of Neonatology, Department of Child Health, Faculty of Medicine University of Indonesia, Cipto Mangunkusumo Hospital, Jakarta, Indonesia

5 Division of Pediatric Intensive Care Unit, Department of Child Health, Faculty of Medicine University of Indonesia, Cipto Mangunkusumo Hospital, Jakarta, Indonesia

6 Division of Radiology, Department of Child Health, Faculty of Medicine University of Indonesia, Cipto Mangunkusumo Hospital, Jakarta, Indonesia cholestasis sepsis. The mediators that trigger released of cytokines are bacterial endotoxin and lipopolysacharides (LPS). ${ }^{1}$ Cholestasis are frequently found in sepsis therefore researchers have intensively seek for the underlying mechanism at molecular level.,, 3

Cholestasis is a clinical syndrome caused by obstruction of biliary outflow with clinical manifestation as follow : jaundice (icteric), dark colored urine, acholic feces (permanent/fluctuative) $)^{4-6}$ and laboratory parameters are an increased in direct bilirubin more than $20 \%$ of total bilirubin. ${ }^{7}$ As for sepsis, it is a severe clinical condition for neonates. Abruption of cholestasis sepsis represents more severe condition in sepsis. Prolonged and incapacitating cholestasis will increased liver disfunction progressing to liver failure, theoretically liver failure is the begining of other organ failure. ${ }^{8}$

Justified diagnostic approach are required in management of intrahepatic cholestasis in neonatal sepsis at early 
stage to prevent sequelle so the child can grow and develop optimally. ${ }^{9}$

This study aim to find out the incidence of intrahepatic cholestasis in neonatal sepsis patients, associated risk factors and mortality rate of cholestasis sepsis in neonates.

\section{METHODS}

Design of study is prospective cohort with no equivalent control group. It was perform by daily clinical assessment of neonatal sepsis patients from the first day of admission until they are released from or died at the Neonatology ward Cipto Mangunkusumo General National Hospital. The study took place in Neonatology ward and Neonatal Intensive Care Unit (NICU) Department of Child Health Faculty of Medicine University of Indonesia-Cipto Mangunkusumo General National Hospital. Duration of study is 5 months, from February 2007 to June 2007.

Inclucion criteria of subjects: neonates with suspect sepsis, no previous record of antibiotics or antifungal treatment, and had permission from the parents. Exclusion criteria are: off coloured three portion feces, possible metabolic disorders or chromosomal aberation based on anamnesis and physical examination, family history of intrahepatic disease with unknown cause or recurrence, evidence of viral or parasitic infection, possible immunological defect or blood dyscrasia based on anamnesis and physical examination; history of hypoperfused shock.

In all patients with suspect neonatal sepsis, data on identity was recorded. They are name, medical record number, birth date/age, sex, birth weight, length at birth, home address, date of admission, refered or born in another hospital, and other cholestatic risk factors that was tested in this study. Informed concent was obtained from parents as sign of agreement to participate in the study. Patients were then classified as cholestasis-sepsis group and noncholestasis-sepsis group.

Peripheral venous blood were withdrawn from the patients with a volume of $2,5 \mathrm{ml}$ and diagnostic work up was performed on the first day of admission: complete blood count, level of C-reactive protein (CRP), IT ratio and blood culture. Urine bilirubin test were performed on the third, fifth, seventh, ninth, eleventh, and thirteenth day unless positive 1 result had been obtain earlier than one of the day mentioned, then the urine biliary test was stopped. Afterwards, further blood tests were performed (another $2.5 \mathrm{ml}$ of peripheral blood were drawn) in order to check total bilirubin concentration, direct bilirubin concentration, ALT, AST and $\gamma \mathrm{GT}$.

Proceeding management of the patients were adjusted accordingly to standard management procedure of neonatal sepsis at Neonatology Division Department of Child Health Faculty of Medicine University of Indonesia-Cipto Mangunkusumo National General Hospital.

Two categories used to classified neonatal sepsis which is suspected infection and proven infection. Proven infection is based on the finding of microbial etiology, while suspected infection is based on risk factors, clinical symptoms and signs and other laboratory result.

Data was analysed using SPSS 12.00, for average number, SD, and 95\% confidence interval. Association between two qualitative variable was analysed with Chi Square test or Fisher exact test. Association between qualitative and quantitative variable was analysed using Student $t$ test or ANOVA.

\section{RESULTS}

From 157 suspect sepsis patients, 19 were excluded from the study. Amongst the exluded cases 5 were uncompliance (they returned home before the successive 14 days urine tests, in these cases there were no evidence of cholestasis), 2 patients were given anti-convulsant drugs, 3 patients were identified with congenital heart defects, 2 patients with down syndrome or facial dysmorphic and 7 patients died before compeleted the examinations.

From 138 subjects included in this study, there were some with exceptionally special circumstances. They were 15 patients with sterile blood culture result, 2 patients with anemia post natal required pack red blood cells transfusion, 12 with metabolic acidosis or hypoglycemia, and 9 with neurological deficits.

According to onset of neonatal sepsis, 118 subjects were early onset sepsis and the other 20 were late onset. 112 subjects $(81,2 \%)$ were born at Cipto Mangunkusumo Hospital while 26 other $(18,8 \%)$ were born at another hospital.

From Table 1 the gestational age of most subjects were less than 38 weeks, with percentage of $55,8 \%$ (77 subjects). Most cases were low birth weight babies (less than 2500 grams) with 24 cases were very low birth weight $(17,4 \%) .80$ subjects were male with percentage 
of $58,0 \%$ and 58 female (42,0\%). Age of patients at the time of sepsis onset mostly are 1 days with total number of 100 patients. Duration of hospitalization mostly are between 15 to 30 days.

Table 1. Subjects characteristics $(n=138)$

\begin{tabular}{|c|c|c|}
\hline Characteristics & Subjects & Percentage \\
\hline \multicolumn{3}{|l|}{ Gestational age (weeks) } \\
\hline$<38$ & 77 & 55,8 \\
\hline $38-42$ & 61 & 44,2 \\
\hline$>42$ & 0 & 0,0 \\
\hline \multicolumn{3}{|l|}{ Birth weight (grams) } \\
\hline$<1500$ & 24 & 17,4 \\
\hline $1500-2499$ & 53 & 38,4 \\
\hline $2500-2999$ & 21 & 15,2 \\
\hline$>3000$ & 40 & 29,0 \\
\hline \multicolumn{3}{|l|}{ Birth place } \\
\hline Cipto Mangunkusumo Hospital & 112 & 81,2 \\
\hline Other hospital & 26 & 18,8 \\
\hline \multicolumn{3}{|l|}{ Sex } \\
\hline Male & 80 & 58,2 \\
\hline Female & 58 & 42,0 \\
\hline \multicolumn{3}{|l|}{ Age group } \\
\hline $1 \mathrm{hr}$ & 100 & 72,5 \\
\hline $2-7 \mathrm{hr}$ & 29 & 21,0 \\
\hline $8+\mathrm{hr}$ & 9 & 6,5 \\
\hline \multicolumn{3}{|l|}{ Duration of hospitalization (days) } \\
\hline$<15$ & 40 & 29,0 \\
\hline $15-30$ & 64 & 46,4 \\
\hline$>30$ & 34 & 24,6 \\
\hline
\end{tabular}

Table 2 showed that the most frequent etiology of cholestasis sepsis was Acinetobacter calcoaceticus with total number of 37 patients.

Tabel 2. Microbial etiology of cholestasis sepsis

\begin{tabular}{lcc}
\hline Blood culture result & $\begin{array}{c}\text { Cholestasis (+) } \\
\text { Total }\end{array}$ & $\begin{array}{c}\text { Cholestasis (-) } \\
\text { Jumlah }\end{array}$ \\
\hline Acinetobacter calcoaceticus & 37 & 20 \\
Enterobacter aerogenes & 14 & 8 \\
Klebsiella pneumoniae & 13 & 2 \\
Serratia marcescens & 8 & 1 \\
Pseudomonas sp & 4 & 0 \\
Escherichia coli & 3 & 1 \\
Serratia liquefaciens & 2 & 1 \\
Staphylococcus epidermidis & 2 & 2 \\
Bacillus sp & 1 & 0 \\
Staphylococcus aureus & 1 & 0 \\
Streptococcus anhaemolityc & 2 & 0 \\
Sterile & 4 & 12 \\
\hline Total & 91 & 47
\end{tabular}

Table 3. showed clinical manifestations of neonatal sepsis with most frequent signs are respiratory distress such as dyspnea, apnea, tachypnea.

Laboratory result showed total leucocyte number between $5000-10.000 / \mu \mathrm{L}$ were found in 54 subjects $(39,1 \%)$. Thrombocyte count of less than $100.000 / \mu \mathrm{L}$ were found in 103 subjects $(74,6 \%)$. CRP level more than $10 \mathrm{mg} / \mathrm{dL}$ were found in 123 subjects $(89,1 \%)$. ITratio of more than 0,10 were found in 102 kasus $(73,9 \%)$.

Table 3. Clinical manifestations

\begin{tabular}{lcc}
\hline Clinical manifestation & $\boldsymbol{\Sigma}(\mathbf{n}=\mathbf{1 0 0})$ & Percentage \\
\hline Respiratory distress & 111 & 80,4 \\
Icterus & 81 & 44,2 \\
Lethargy & 74 & 53,6 \\
Acholic feces & 52 & 37,7 \\
Hyperthermia & 46 & 33,3 \\
Hypothermia & 45 & 32,6 \\
Hepatomegaly & 34 & 24,6 \\
Abdominal distention & 32 & 23,2 \\
$\quad$ (bloating) & & \\
Vomiting & 6 & 4,3 \\
\hline
\end{tabular}

Table 4 showed that 91 proven cholestasis sepsis subjects have increased direct bilirubin concentration about 55,3\% from totalbilirubin concentration. Average concentration for ALT, AST, and $\gamma$ GT were within normal ranges at the beginning of cholestasis.

Table 5 showed associated risk factors with the occurence of cholestasis : sex, age at the time of admission, birth place, birth weight, birth height, prematurity, low birth weight, early onset sepsis.

Table 6 showed risk factors from laboratory result as sepsis indicator at the time of admission: leucocyte number, thrombocyte number, CRP concentration, and IT ratio with occurrence of cholestasis. 
Table 4. Concentration of bilirubin, ALT,AST and $\gamma \mathrm{GT}(\mathrm{n}=91)$

\begin{tabular}{lccccc}
\hline \multirow{2}{*}{ Variable } & Mean & SD & \multicolumn{2}{c}{ 95\% CI } & Med \\
\cline { 4 - 5 } & & & Low & High & 7.0 \\
Direct bilirubin $(\mathrm{n}=91)$ & 8.8 & 7.0 & 7.3 & 10.2 & 15.3 \\
Total Bilirubin (n=91) & 15.9 & 9.8 & 13.9 & 18.0 & 36.0 \\
ALT (n=91) & 56.3 & 57.9 & 44.4 & 68.2 & 65.0 \\
AST (n=91) & 86.0 & 79.9 & 69.6 & 102.4 & 129.0 \\
$\gamma$ GT $(\mathrm{n}=91)$ & 138.6 & 64.3 & 125.3 & 151.8 & \\
\hline
\end{tabular}

Table 5. Risk factors associated with the occurence of cholestasis sepsis

\begin{tabular}{|c|c|c|c|c|c|c|}
\hline \multirow{2}{*}{ Risk Factors } & \multicolumn{2}{|c|}{ Cholestasis } & \multirow{2}{*}{$\mathbf{P}$} & \multirow{2}{*}{$\mathbf{R R}$} & \multicolumn{2}{|c|}{$95 \% \mathrm{CI}$} \\
\hline & Pos & Neg & & & Low & High \\
\hline \multicolumn{7}{|l|}{ Sex } \\
\hline Male & 54 & 26 & 0,786 & 1,06 & $\mathbf{0 , 8 3}$ & 1,35 \\
\hline Female & 37 & 21 & & & & \\
\hline \multicolumn{7}{|l|}{ Age (day) } \\
\hline 1 & 64 & 36 & 0,562 & 0,90 & 0,70 & 1,16 \\
\hline$\geq 2$ & 27 & 11 & & & & \\
\hline \multicolumn{7}{|l|}{ Birth place } \\
\hline CiptoMangunkusumo hospital & 72 & 40 & 0,616 & 0,89 & 0,67 & 1,18 \\
\hline Other hospital & 19 & 7 & & & & \\
\hline \multicolumn{7}{|l|}{ Birth weight (grams) } \\
\hline$<1500$ & 17 & 7 & 0,683 & 1,13 & $\mathbf{0 , 8 0}$ & 1,61 \\
\hline $1500-2499$ & 34 & 19 & 0,957 & 1,03 & 0,75 & 1,40 \\
\hline $2500-2999$ & 15 & 6 & 1,679 & 1,14 & 0,80 & 1,64 \\
\hline$\geq 3000$ & 25 & 15 & & & & \\
\hline \multicolumn{7}{|l|}{ Prematurity } \\
\hline Yes & 48 & 29 & 0,411 & $\mathbf{0 , 8 8}$ & 0,70 & 1,12 \\
\hline No & 43 & 18 & & & & \\
\hline \multicolumn{7}{|l|}{ Early onset sepsis } \\
\hline Yes & 75 & 43 & 0.238 & 0.79 & 0.61 & 1.03 \\
\hline No & 16 & 4 & & & & \\
\hline
\end{tabular}

Table 6. Laboratory result risk factors associated with cholestasis sepsis

\begin{tabular}{|c|c|c|c|c|c|c|}
\hline \multirow{2}{*}{ Risk factors } & \multicolumn{2}{|c|}{ Cholestasis } & \multirow{2}{*}{$\mathbf{P}$} & \multirow{2}{*}{$\mathbf{R R}$} & \multicolumn{2}{|c|}{$95 \%$ CI } \\
\hline & Pos & Neg & & & Low & High \\
\hline \multicolumn{7}{|l|}{ Leucocyte count } \\
\hline$<5000 / \mu \mathrm{L}$ & 26 & 10 & 0,102 & 1,36 & 0,99 & 1,88 \\
\hline $5000-10000 / \mu \mathrm{L}$ & 39 & 15 & & & & \\
\hline$>10000 / \mu \mathrm{L}$ & 26 & 22 & 0,092 & 1,33 & 0,98 & 1,81 \\
\hline \multicolumn{7}{|l|}{ CRP } \\
\hline$\leq 10 \mathrm{mg} / \mathrm{dL}$ & 9 & 6 & 0,821 & 0,90 & 0,59 & 1,39 \\
\hline$>10 \mathrm{mg} / \mathrm{dL}$ & 82 & 41 & & & & \\
\hline \multicolumn{7}{|l|}{ IT ratio } \\
\hline$\leq 0.10$ & 19 & 17 & 0,083 & 0,75 & 0,54 & 1,04 \\
\hline$>0.10$ & 72 & 30 & & & & \\
\hline
\end{tabular}


Table 7 showed other risk factors such as duration of hospitalization, fasting period, total parenteral nutrition duration, bacterial etiology and clinical manifestations (vomiting, lethargy, icterus, hepatomegaly, abdominal distention, fluctuative acholic feces and respiratory distress associated with the occurrence of cholestasis.
Result of urine bilirubin were classified as positive 1, 2 and 3. Picture 1 showed that most neonatal sepsis had postive 1 result on day-7 with 17 subjects of total 91 cholestasis subjects. The onset of cholestasis in neonatal sepsis with median on day-7 from 91 cholestasis subjects.

Table 7. Other risk factors associated with cholestasis sepsis

\begin{tabular}{|c|c|c|c|c|c|c|}
\hline \multirow{2}{*}{ Risk factors } & \multicolumn{2}{|c|}{ Cholestasis } & \multirow{2}{*}{$\mathbf{P}$} & \multirow{2}{*}{$\mathbf{R R}$} & \multicolumn{2}{|c|}{$95 \% \mathrm{CI}$} \\
\hline & Pos & Neg & & & Low & High \\
\hline \multicolumn{7}{|c|}{ Duration of hospitalization (days) } \\
\hline$\geq 15$ & 78 & 20 & 0,000 & 2,45 & 1,55 & 3,87 \\
\hline$\overline{<} 15$ & 13 & 27 & & & & \\
\hline \multicolumn{7}{|l|}{ Bacterial etiology } \\
\hline Positive gram & 6 & 2 & 1,000 & 1,06 & 0,70 & 1,60 \\
\hline Negative gram & 81 & 33 & & & & \\
\hline \multicolumn{7}{|l|}{ Vomiting } \\
\hline Yes & 3 & 3 & 0,409 & 0,75 & 0,33 & 1,68 \\
\hline No & 88 & 44 & & & & \\
\hline \multicolumn{7}{|l|}{ Lethargy } \\
\hline Yes & 53 & 21 & 0,182 & 1,21 & 0,94 & 1,55 \\
\hline No & 38 & 26 & & & & \\
\hline \multicolumn{7}{|l|}{ Icterus } \\
\hline Yes & 55 & 6 & 0,000 & 1,93 & 1,50 & 2,48 \\
\hline No & 36 & 41 & & & & \\
\hline \multicolumn{7}{|l|}{ Hepatomegaly } \\
\hline Yes & 32 & 2 & 0,000 & 1,66 & 1,38 & 2,00 \\
\hline No & 59 & 45 & & & & \\
\hline \multicolumn{7}{|l|}{ Abdominal distension } \\
\hline Yes & 26 & 6 & 0,061 & 1,33 & 1,06 & 1,66 \\
\hline No & 65 & 41 & & & & \\
\hline \multicolumn{7}{|l|}{ Acholic feces } \\
\hline Yes & 45 & 7 & 0,000 & 1,62 & 1,29 & 2,02 \\
\hline No & 46 & 40 & & & & \\
\hline \multicolumn{7}{|l|}{ Respiratory distress } \\
\hline Yes & 68 & 43 & 0,033 & 0,72 & 0,58 & 0,89 \\
\hline No & 23 & 4 & & & & \\
\hline
\end{tabular}

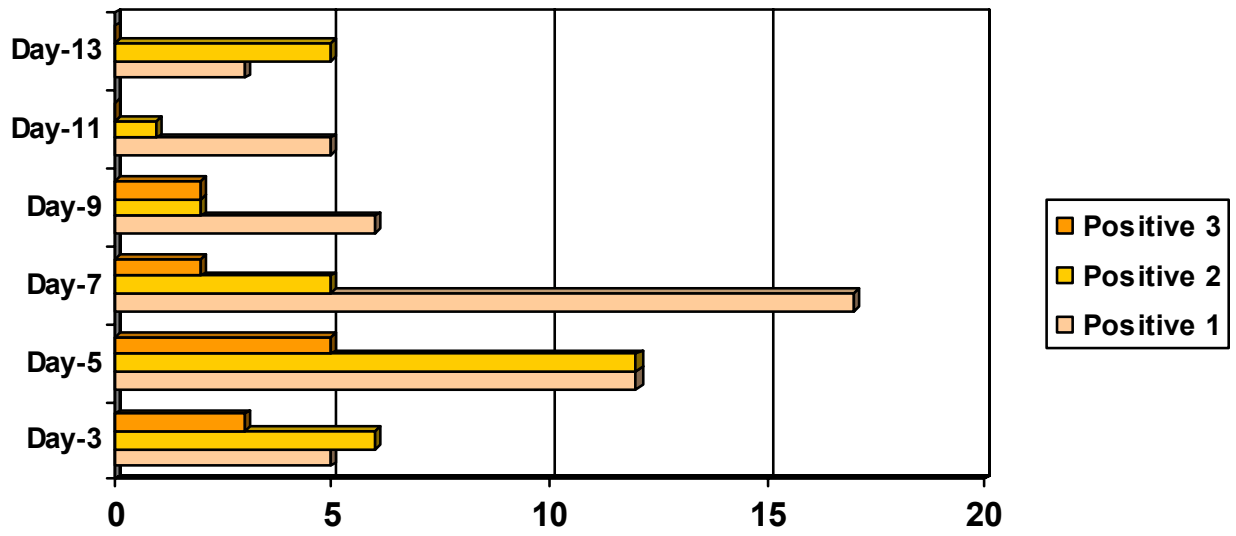

Figure 1. Urine bilirubin positive result according to day of examination 
Number of neonatal mortality due to sepsis in this study is $59(42,8 \%)$. While mortality rate of cholestasis sepsis from this study is 48 from 91 cholestasis subjects $(52,8 \%)$ with $\mathrm{p}=0,002, \mathrm{RR}=2,25(1,30-3,92)$.

Table 8 . Relative risk of cholestasis sepsis and mortality

\begin{tabular}{|c|c|c|c|}
\hline \multirow{2}{*}{ Cholestasis } & \multicolumn{2}{|c|}{ Mortality } & \multirow[t]{2}{*}{ Total } \\
\hline & Yes & No & \\
\hline Positive & 48 & 43 & 91 \\
\hline Negative & 11 & 36 & 47 \\
\hline Total & 59 & 79 & 138 \\
\hline
\end{tabular}

\section{DISCUSSION}

Most neonatal with sepsis in this study have low birth weight which is less than 2500 grams as many as 77 subjects $(55,8 \%)$, with peak birth weight group between 1500-2499 grams. According to study by Shamir ${ }^{10}$ et al, birth weight of less than 2500 grams group are the highest population with gram negative sepsis. Other finding in this study that is in accordance with study by Shamir et al is that gestational age of less than 38 weeks are the most frequent group with gram negative sepsis. Pre-term neonates (gestational age $<38$ weeks) are immature, their immune system are inadequate therefore they are susceptible to infection. ${ }^{11}$

In this study we found the incidence of neonatal cholestasis sepsis is $65,9 \%$, lower compare to previous study done by Oswari et al. ${ }^{12}$ The study by Oswari was a retrospective study showed occurrence of cholestasis in 47 sepsis neonates at NICU and Neonatology ward Cipto Mangunkusumo National General Hospital with percentage of $74,5 \%$ proven sepsis. The difference with our study, we use larger sample size and included both proven and clinical sepsis. There hasn'nt been any report from other countries about the incidence of cholestasis sepsis either proven or clinical sepsis.

Microbial etiology spectrum of neonatal sepsis differs in each hospital. In this study microbial etiology of neonatal sepsis is gram negative bacteria $(82,6 \%)$, with the most frequently found Acinetobacter calcoaceticus (41,3\%) followed by Enterobacter aerogenes (15,9\%) and Klebsiella pneumoniae (10,9\%). Our result is similar with reports from several refferrence that stated most neonatal sepsis are caused by gram negative bacteria. ${ }^{13}$ Nevertheless in our study, Fisher exact test failed to reveal significant correlation between gram negative bacteria and cholestasis occurrence.
Similar microbial etiology result were found in previous study by Oswari ${ }^{12}$ et al. They found the most frequent microbial etiology of neonatal cholestasis sepsis is Acinetobacter calcoaceticus with percentage of $58,6 \%$. Data analysis from our study found no significant correlation between Acinetobacter calcoaceticus with the occurrence of cholestasis, $p=0,975 \mathrm{RR}=0,97(0,76$ 1,24). Tiker ${ }^{13}$ et al report Escherichia coli is still the number one gram negative bacteria that caused neonatal cholestasis sepsis at neonatology ward (46,6.\%), followed by Klebsiella pneumoniae and Pseudomonas aeruginosa. Positive gram bacteria as etiology from our study is Staphylococcus aureus $(20,0 \%)$, and coagulase-negative Staphylococcus spp (13,0\%).

Amongst clinical criteria for neonatal sepsis such as unstable respiratory rate and lethargy are the most frequently found signs in our study. Respiratory distress accordingly are dyspnea, apnea, tachypnea with total percentage of $80,4 \%$. Lethargy with percentage of $53,6 \%$. Tiker ${ }^{13}$ et al found perinatal hypoxia can caused increased direct bilirubin, however further explanation of the mechanism is lacking.

From 91 cholestasis subjects, direct bilirubin concentration increased 55,3\% from total bilirubin. Tiker ${ }^{13}$ et al found increased direct bilirubin $44,1 \%$ from total bilirubin (average direct bilirubin is $12,9 \mathrm{mg} / \mathrm{dL}$, from average total bilirubin $29,2 \mathrm{mg} / \mathrm{dL}$ ). Shamir ${ }^{10}$ et al found increased direct bilirubin $29,7 \%$ from total bilirubin, (direct bilirubin $3,3 \pm 4,7 \mathrm{mg} / \mathrm{dL}$, from total bilirubin $11,1 \pm 5,2 \mathrm{mg} / \mathrm{dL}$ ). Increased level of direct bilirubin in this study is higher, this is due to possible gram negative bacteria sepsis are different or because difference in duration of fasting, therefore further research is required. The effect of duration of fasting in gram negative sepsis neonates are the longer period of fasting will increased direct bilirubin more pronounced than shorter fasting period. ${ }^{10}$

In our study, most cases of neonatal cholestasis sepsis $(52,8 \%)$ ended with mortality. From this result, relative risk of neonatal cholestasis is $2.25(1,30-3,92)$. The presence of cholestasis in neonatal sepsis implicates in increased mortality rate, therefore cholestasis can be used as prognostic factor for mortality in neonatal sepsis patients. Up till now, lack of studies addressing this issue specifically.

It is concluded that the incidence of cholestasis sepsis in neonates at Neonatology ward and NICU Cipto Mangunkusumo Hospital is $65,9 \%$ with most frequent 
etiology is Acinetobacter calcoaceticus (40,6\%). Risk factors associated with the occurrence of neonatal cholestasis sepsis are statistically insignificant, therefore further study is required. Onset of intrahepatic cholestasis in neonatal sepsis occured mostly on day-7. Mortality rate of neonatal cholestasis sepsis is $52,8 \%$.

\section{REFERENCES}

1. Elferink RO. Cholestasis. Gut 2003;52:1142-8.

2. Lee T, Boyer JL. Molecular alterations in hepatocyte transport: mechanisms in acquired cholestatic liver disorders. Seminars in liver disease 2000;20:373-84.

3. Strazzabosco M, Spirili C, Okolicsanyi I. Pathophysiology of intrahepatic biliary epithelium. J Gastroenterol 2000; 15:244-53.

4. Emerick KM, Whitington PF. Molecular basis of neonatal cholestasis. Pediatr Clin North Am 2002;49:221-35.

5. Suchy FJ. Approach to the infant with cholestasis. In: Suchy FJ, Sokol RJ, Balistreri WF, editors. Liver disease in children. $2^{\text {nd }}$ ed. Philadelphia: Lippincott Williams \& Wilkins; 2001. p.187-94.

6. Bisanto J. Kolestasis pada bayi. In: Trihono PP, Purnamawati S, Syarif DR, Hegar B, Gunardi H, Oswari H, dkk, editors. Hot topics in Child Health II. Naskah lengkap pendidikan kedokteran berkelanjutan Ilmu Kesehatan Anak FKUI XLV; 18-19 Februari 2002. Jakarta: Balai Penerbit FKUI; 2002. p.84-99.
7. Moyer V, Freese DK, Whitington PF, Olson AD, Brewer F. Guideline for the evaluation of cholestatic jaundice in infants: recomendation of the North American Society for Pediatric Gastroenterology, Hepatology and Nutrition. J Pediatr Gastroenterol Nutr 2004;39:115-28.

8. Sharma S, Eschun G. Multisystem organ failure of sepsis. (accessed on Sept 1, 2007). Available from: http://www. emedicine.com.

9. Rosenthal P. Neonatal hepatitis and congenital infections. In: Suchy FJ, Sokol RJ, Balistreri WF, editors. Liver disease in children. $3^{\text {rd }}$ ed. Philadelphia: Lippincott Williams \& Wilkins; 2001:p.239-52.

10. Shamir R, Metzger AM, Bujanover Y, Ashkenazi S, Dinari G, Sirota L. Liver enzyme abnormalities in gram-negative bacteremia of premature infants. Pediatr Infect Dis J 2000; 19:495-8.

11. Moore DL. Infections in newborn nurseries and neonatal intensive care units. In: Mayhall CG, editors. Hospital epidemiology and infection control. $3^{\text {rd }}$ ed. Philadelphia: Lippincott Williams \& Wilkins, 2004.p.851-82.

12. Oswari H, Siagian M, Bisanto J. Neonatal liver disease in Cipto Mangunkusumo Hospital. Abstract KONIKA XIII; 4-7 Juli 2005; Bandung, Indonesia.

13. Tiker F, Tarcan A, Killicdag H, Gurakan B. Early onset conjugated hyperbilirubinemia in newborn infants. Indian J Pediatr 2006;73:409-12.

14. Haque KN. Definitions of blood stream infection in the newborn. Pediatr Crit Care Med 2005;6:45-9. 